\title{
SOSIALISASI PEMBELAJARAN SASTRA BERPERSPEKTIF JENDER BAGI GURU SMA/SMK SE-SURAKARTA
}

\author{
Rahmah Purwahida dan Miftakhul Huda \\ Program Studi PBSID - FKIP \\ Universitas Muhammadiyah Surakarta
}

\begin{abstract}
Socialization purposes, namely (1) socialization that participants are able to understand and master the learning literature a gender perspective in terms of curriculum, teaching materials, and learning strategies in the classroom and (2) conducted a follow-up of this activity in the form of training activities, learning materials utilization literature a gender perspective. Socialization is given to high school teachers and vocational as Surakarta. The method adopted in this training include: seminars, frequently asked questions, and discussion. Socialization lasted one day with the number of participants 19 persons. Evaluation of this activity is done in the process. During the training activities the participants enthusiastic, passionate, active and responsive. Through this socialization of teachers get the necessary materials related strategies, methods and teaching materials literature a gender perspective. The teachers are motivated to understand gender issues in a comprehensive manner. Insights teachers to manage learning an enjoyable literary gender perspective in the classroom increases. It is because any discussion of solutions of the constraints experienced by teachers in teaching literature a gender perspective.
\end{abstract}

Kata-kata kunci: pembelajaran, sastra, jender

\section{PENDAHULUAN}

\section{Analisis Situasi}

Perjuangan gerakan feminisme Indonesia dalam menuntut persamaan hak antara laki-laki dan perempuan telah membuahkan hasil yang cukup signifikan. Salah satunya ditandai dengan Instruksi Presiden Nomor 9 Tahun 2000, berupa keputusan untuk melakukan Gender Mainstreaming dalam berbagai aspek pembangunan di Indonesia.

Sejalan dengan upaya pemerintah, seharusnya dalam ranah pembelajaran, termasuk pembelajaran bahasa dan sastra Indonesia di sekolah dasar, menengah, maupun perguruan tinggi pun diharapkan tidak melupakan perspektif jender. Namun, hingga kini pembelajaran sastra di sekolah dasar, menengah, sampai perguruan tinggi masih sangat kental dengan bias jender (Wiyatmi, 2008: 5). Hal itu terlihat dari masih banyaknya buku teks Bahasa Indonesia SD, SMP, SMA dan perguruan tinggi yang menggunakan kutipan karya sastra dan contoh-contoh kalimat atau ulasan yang bias jender (Irawan, 2008: 1). Buku-buku Sejarah Sastra yang 
digunakan di perguruan tinggi, misalnya buku-buku karya Umar Junus, yaitu Perkembangan Novel Indonesia Modern (1984) dan Perkembangan Puisi Indonesia dan Melayu Modern (1981) masih menampakkan bias jender, karena hanya sejumlah kecil karya sastra yang bermuatan jender dan karya sastra milik (Toety Heraty dan Nh. Dini) pengarang perempuan maupun karyanya dibahas dalam buku tersebut.

Pembelajaran sastra berprespektif jender penting dilaksanakan mengingat melalui pembelajaran sastra yang berprespektif jender diharapkan terjadi penanaman nilai-nilai keadilan dan kesetaraan jender pada generasi muda sehingga tercipta masyarakat yang berkeadilan jender dan saling menghormati dan menghargai antarsesama. Agar gagasan pembelajaran sastra dapat tercapai, maka ada sejumlah hal yang perlu diperhatikan, antara lain kurikulum, materi pembelajaran, strategi pembelajaran yang berprespektif jender, serta guru yang sensitif jender (Wiyatmi, 2008: 6).

Kurikulum, materi pembelajaran, dan cara pembelajaran yang berprespektif jender tidak akan berarti apa-apa tanpa kompetensi guru yang sensitif jender. Hal itu dibuktikan melalui hasil penelitian Kusumaningrum (2007) bahwa guru sangat dibutuhkan dalam mentransformasi pengetahuan dan nilai-nilai kehidupan pada diri anak-anak, proses ini membentuk perkembangan pola pikir, tingkah laku dan mozaik kepribadian manusia sebagai mahluk sosial, termasuk di dalamnya pandangan mengenai peran manusia berdasarkan jenis seks atau peran jender. Oleh karena itu, untuk menanamkan nilai-nilai keadilan dan kesetaraan jender pada generasi muda sehingga tercipta masyarakat yang berkeadilan jender dan saling menghormati dan menghargai antarsesama, guru bukan hanya menyampaikan materi pembelajaran secara harfiah saja, tetapi juga melakukan interpretasi terhadap materi yang disampaikan. Guru yang sensitif jender, tentu akan menginterpretasi materi pembelajaran. Berbeda dengan guru yang belum memahami jender, tentu akan kesulitan daalm menginterpretasi materi pembelajaran sehingga pesan atau ideoogi jender yang terdapat dalam karya sastra sulit untuk dipahami oleh siswa dan siswa pun tidak akan memiliki perhatian terhadap keadilan dan kesetaraan jender. Dengan demikian, untuk mencapai pembelajaran sastra yang berperspektif jender, penting disiapkan guru yang sensitif jender.

Persiapan membentuk guru sastra yang sensitif jender dibutuhkan peran perguruan tinggi (FKIP dan Program Studi Kependidikan) untuk senantiasa melakukan inovasiinovasi pembelajaran dalam rangka menghasilkan para guru yang memiliki sensitif jender. Di samping itu, dibutuhkan kerja sama perguruan tinggi, Pusat Studi Jender atau Wanita, dan lembaga-lembaga sosial dengan pihak Depdiknas untuk melakukan sosialisasi kesetaraan jender dan analisis jender, terutama dalam bidang pembelajaran bagi para guru.

Persoalan menyiapkan calon guru dan guru yang kompeten dalam pembelajaran sastra berperspektif jender di Surakarta sudah seharusnya ditangani serius oleh Program Studi Pendidikan Bahasa dan Sastra Indonesia dan Daerah FKIP UMS, sebagai salah satu jurusan/prodi dengan jumlah mahasiswa PBSID yang besar dibandingkan jurusan/prodi di perguruan tinggi lainnya di Surakarta. Tri Darma Perguruan Tinggi, salah satunya adalah pengabdian kepada masyarakat, menjadi latar belakang kegiatan pengabdian ini dilaksanakan sebagai upaya memberikan pemahaman guru SMA/SMK se-Surakarta mengenai pembelajaran sastra berperspektif jender.

Sosialisasi pembelajaran sastra berperspektif jender bagi guru SMA/SMK se-Surakarta ini penting dilaksanakan dengan 
pertimbangan adanya kebutuhan dari guru SMA/SMK se-Surakarta untuk memahami pembelajaran sastra berperspektif jender dari pihak akademisi maupun sastrawan yang memiliki minat memperjuangkan keadilan dan kesetaraan jender. Sastrawan memiliki kompetensi dalam hal melahirkan karya sastra dan akademisi berkompeten dalam hal memanfaatkan karya sastra dalam pengelolaan pembelajaran sastra yang berperspektif jender. Sosialisasi ini akan disampaikan oleh akademisi dan sastrawan; Abidah El Khalieqy yang telah dikenal masyarakat melalui karya-karyanya yang bernafaskan jender dan Islam.

Kelebihan sosialisasi ini sehingga urgen untuk dilaksanakan adalah adanya perpaduan pandangan dari akademisi dan sastrawan dalam memberikan pemahaman komprehensif kepada guru SMA/SMK seSurakarta mengenai pembelajaran sastra berperspektif jender. Pemahaman komprehensif tersebut dibutuhkan para guru sastra untuk mampu mendesain pembelajaran, mulai dari memilih materi ajar hingga menyampaikan tujuan pembelajaran sastra berperspektif jender di kelas. Pemahaman komprehensif yang dimaksud dalam kegiatan ini dapat diindikasikan dari adanya perpaduan saran mengenai pemilihan materi ajar antara sastrawan dan akdemisi. Saran mengenai pemilihan materi ajar dari sastrawan yang menggeluti dunia sastra berperspektif jender seperti Abidah El Khalieqy menjadi penting untuk membuka khasanah pengetahuan guru sastra. Akademisi pun akan memiliki berbagai pandangan mengenai hal tersebut ditambah pengetahuan mengenai kurikulum dan strategi pembelajaran sastra berperspektif jender di kelas.

Sosialisasi yang mengolaborasikan pembicara dari akademisi dan sastrawan; Abidah El Khalieqy yang konsen memperjuangkan kesetaraan dan keadilan jender tepat dilakukan dalam rangka memperingati hari Kartini sebagai tokoh pergerakan emansipasi wanita. Momentum ini diharapkan dapat menghidupkan semangat para guru sastra dalam memahami dan menerapkan pembelajaran sastra yang berperspektif jender.

\section{Perumusan Masalah}

Rumusan masalah yang akan dijawab dalam program pengabdian ini, yaitu (1) bagaimanakah upaya memberikan pemahaman mengenai pembelajaran sastra berperspektif jender dari sisi kurikulum, materi ajar dan strategi pembelajaran di kelas bagi guru SMA/SMK se-Surakarta dan (2) bagaimanakah membentuk guru sastra seSurakarta yang sensitif jender.

\section{Tinjauan Pustaka}

a. Pembelajaran Sastra

Pembelajaran sastra merupakan proses belajar mengajar sastra yang dilakukan guru dan siswa dalam rangka menjadikan perilaku siswa sesuai dengan tujuan yang telah ditetapkan (Purwahida, 2008: 7). Komponen pembelajaran sastra terdiri dari guru, siswa, tujuan, bahan pembelajaran (materi), metode, media pembelajaran dan evaluasi (Endraswara, 2005: 3).

Pembelajaran sastra sebagai bagian dari sistem pendidikan nasional berfungsi untuk mengembangkan kemampuan serta meningkatkan mutu kehidupan dan martabat manusia Indonesia dalam rangka mewujud-kan tujuan pendidikan nasional. Sumbangsih pembelajaran sastra yang terbaik adalah sesuai dengan hakikat sastra, sebagai seni, sebagai bagian dari budaya. Pembelajaran sastra merupakan pembelajaran seni sastra, bagian dari pendidikan seni, bagian dari pendidikan budaya. Sastra sebagai seni merupakan kegiatan kreatif dan pengalaman jiwa manusia yang dijelmakan ke 
dalam medium bahasa. Oleh karena itu, pembelajaran sastra adalah pembelajaran kreativitas dan ekspresi.

Kegiatan pembelajaran harus merupakan bagian dari usaha pendidikan. Pendidikan dan pembelajaran merupakan suatu kegiatan yang seiring dan sejalan karena pembelajaran merupakan sebagian dari kegiatan pendidikan. Pembelajaran lebih menekankan pada usaha pemindahan (pewarisan) pengetahuan, kecakapan, dan pembinaan keterampilan kepada siswa, sedangkan pendidikan lebih menekankan kepada usaha pembentukkan nilai-nilai hidup, sikap, dan pribadi siswa. Dengan menghayati dan memahami sastra, siswa dapat mengenal dan menghargai nilai. Nilai yang dijunjung oleh bangsa, memperoleh bandingan untuk dapat menghargai hidup, memperoleh kenikmatan dalam mengutarakan diri melalui ekspresi orang lain.

Menurut Sayuti (1994: 21), melalui karya sastra yang mengandung berbagai kemungkinan moral, sosial, dan psikologis, orang dapat lebih cepat mencapai kemantapan dalam bersikap yang diwujudkan dalam perilaku dan pertimbangan pikiran yang dewasa. Dengan memasuki "segala macam situasi” dalam karya sastra, seseorang akan dapat menempatkan diri pada kehidupan yang lebih luas dari situasi dirinya yang nyata. Sastra memberikan pengalaman batin yang menjadikan siswa memiliki bekal dalam memecahkan persoalan yang serupa dalam duni nyata berdasarkan realitas karya sastra yang dibacanya.

Menurut Endraswara (2005: 65), pembelajaran sastra dikatakan berhasil bila siswa berpribadi sastra, yaitu menjadi insan peminat atau pecinta sastra. Seorang peminat atau pecinta sastra memiliki ciri-ciri berikut ini.
1) Gemar membaca, mendengarkan, dan menonton pertunjukkan sastra.

2) Gemar membicarakan dan mendialogkan kepada orang lain dari apa yang dilihat, dirasakan, dan dihayati dalam karya sastra.

3) Suka mengumpulkan karya-karya sastra, mengkliping beberapa karya yang diminatinya.

4) Sering membaca ulasan, sorotan, timbangan sastra yang ada di media massa.

5) Gemar mengikuti aneka macam lomba sastra untuk meningkatkan dan menguji kemampuan.

\section{b. Pembelajaran Sastra Berperspektif Jender}

Jender mengacu pada suatu sifat yang melekat pada kaum laki-laki maupun perempuan yang dikonstruksi secara sosial maupun kultural (Macdonald, 1997: 3). Jender berasal dari bahasa Latin, yaitu "genus", berarti tipe atau jenis (Susilaningsih, 2004: 3). Jadi, jender adalah sifat dan perilaku yang dilekatkan pada laki-laki dan perempuan yang dibentuk secara sosial maupun budaya. Karena dibentuk oleh sosial dan budaya setempat, maka jender tidak berlaku selamanya tergantung kepada waktu dan tempatnya.

Pembelajaran berperspektif jender dalam hal ini adalah sebuah proses pendidikan yang dijiwai oleh kesadaran adanya keadilan dan kesetaraan jender. Untuk menunju pembelajaran sastra berperspektif jender, paling tidak ada tiga komponen yang harus diperhatikan, yaitu kurikulum, materi yang disampaikan atau diproduksi oleh institusi pendidikan, dan strategi pembelajaran di kelas (Wiyatmi, 2008: 7). Jadi, pembelajaran sastra berperspektif jender adalah proses belajar mengajar seni sastra yang kreatif dan 
ekspresif yang dijiwai oleh kesadaran adanya keadilan dan kesetaraan jender.

1) Kurikulum Sastra Berprespektif Jender

Gaby Weiner, seorang peneliti di bidang pendidikan dan jender pada tahun 1981-1982 di Inggris pertama kali mencetuskan ide mengenai kurikulum berprespektif jender (Arivia, 2006: 419429). Weiner memiliki pandangan, bahwa kurikulum dalam pandangan feminis merupakan sebuah perjuangan yang mempunyai tujuan untuk menciptakan masyarakat yang berkeadilan jender. Hal ini disebabkan segala relasi kekuasaan antara laki-laki dan perempuan serta segala persoalan kesetaraan selalu akan terefleksi dalam sebuah kurikulum. Penyusunan kurikulum berperspektif jender membutuhkan kerja sama antara para tim pengembang kurikulum di institusi pendidikan dengan para guru sebagai patner dalam mengembangkan, mengimplementasi, dan mengevaluasi kurikulum, dan para feminis sebagai penyeimbang kebijakan.

Pembahasan jender yang dimasukan ke dalam mata pelajaran, salah satunya dalam mata pelajaran Bahasa dan Sastra Indonesia dapat menyalurkan pemahaman mengenai jender kepada siswa-siswa yang menjembatani masyarakat agar teripta masyarakat yang berkeadilan dan memiliki kesetaraan jender. Menurut Wiyatmi (2008: 7) pembahasan jender sebagai wujud dari konstruksi kurikulum berperspektif jender dalam konteks di Perguruan Tinggi, ditandai dengan adanya mata kuliah Kritik Sastra Feminis dan Metode Penelitian dengan Analisis Jender.

2) Materi Pembelajaran Sastra Berperspektif Jender

Pembelajaran sastra berperspektif jender perlu disiapkan materi pembe- lajaran yang menunjukkan adanya kesetaraan jender atau mengkritisi adanya ketidakadilan jender yang terepresentasi pada karya-karya sastra Indonesia, yang menjadi bacaan dalam pembelajaran sastra. Perlu juga diperhatikan aktivitas dan karya-karya para sastrawan perempuan. Melalui pembelajaran sastra berprespektif jender, diharapkan secara pelan-pelan dapat tercipta adanya kesadaran akan pentingnya kesetaraan dan keadilan jender dalam diri para pembelajar.

Pemanfaatan karya-karya yang sudah ada juga sangat tepat dilakukan dalam mempersiakan materi ajar sastra berperspektif jender. Hal itu tepat dilakukan selain secara khusus dilakukan penyusunan bahan ajar sastra yang berprespektif jender. Dapat dipilih karyakarya sastra yang sensitif jender atau karya-karya sastra yang bernuansa feminis, yaitu karya-karya sastra mengandung semangat keadilan dan kesetaraan jender, atau kritis terhadap ketidakadilan jender. Untuk level SMA dan Perguruan Tinggi, misalnya dapat dipilih novel Geni Jora karya Abidah El Khalieqy (2003), yang mengambarkan bagaimana seorang anak perempuan (Kejora) harus menghadapi kultur patriarki di dalam kebudayaan Jawa, yang memandang perempuan (termasuk dirinya, kakak perempuan, ibunya, neneknya, dan teman-temannya) selalu sebagai the other, the second sex (de Beauvoir, 1987), sehingga dia termotivasi untuk selalu meningkatkan pengetahuan dan prestasi agar mampu sejajar dengan para laki-laki.

Selain novel Geni Jora, novel Layar Terkembang (Sutan Takdir Alisyahbana), Tarian Bumi atau Kenanga (Oka Rusmini), dan Burung-burung Manyar (Y.B. Mangunwijaya) juga dapat dijadikan contoh bahan pembelajaran 
karena karya-karya itu dengan kritis mencoba mengkritisi dominasi patriarki dan menunjukkan pentingnya kesetaraan jender.

Novel-novel yang layak dijadikan bahan ajar dalam pembelajaran sastra berperspektif jender, berdasarkan hasil penelitian akan dikemukan berikut ini.

a) Novel Perempuan Badai Karya Mustofa W. Hasyim (2007).

b) Novel Perempuan Jogja Karya Achmad Munif (2006).

c) Novel Durga Umayi karya YB. Mangunwijaya, Para Priyayi karya Umar Kayam, Cau Bau Kan karya Remy Sylado, Saman karya Ayu Utami, Lemah Tanjung karya Ratna Indraswari Ibrahim, Tarian Bumi karya Oka Rusmini, Ronggeng karya Dewi Linggasari, Sintren karya Dianing Widya Yudhistira, dan Perempuan Berkalung Sorban karya Abidah El Khalieqy (2009).

Puisi-puisi karya sejumlah penyair yang bernafaskan jender dapat juga dugunakan sebagaimateri ajar apresiasi pusi dan cerpen berperspektif jender di sekolah maupun perguruan tinggi. Kumpulan puisi M.H Ainun Nadjib; Lautan Jilbab, beberapa puisi sejumlah penyair berikut ini, Toety Heraty, Rita Oetoro, Upita Agustine, Agnes Sri Hartini Arswendo, Poppy Hutagalung, Ulfatin, Dhenok Kristianty, Dorothea Rosa Herliany, Lia Aminuddin, dan Nana Ernawaty dapat dijadikan materi ajar dalam pembelajaran sastra berperspektif jender. Alasannya, karena puisi-puisi karya penyair-penyair tersebut mempertanyakan kodrat perempuan yang harus disamakan dengan laki-laki, dan juga perjuangan hidup bersama dalam rumah tangga yang sering membelenggu perempuan serta rasa cemburu yang coba ditampilkan adalah ekspresi perjuangan jender.
Cerpen karya-karya sejumlah pengarang seperti Titis Basino berjudul Pelabuhan Hati, Cerpen Zina karya Putu Wijaya dan sejumlah cerpen lainnya karya Helvy Tiana Rosa, Nenden.A.Lilis, Danarto dapat pula dijadikan materi ajar dalam pembelajaran sastra berperspektif jender.

3) Strategi Pembelajaran Sastra Berperspektif Jender

Keberhasilan pembelajaran juga sangat ditentukan oleh aktivitas pembelajaran di kelas. Untuk mencapai tujuan pembelajaran yang berkeadilan jender, para feminis dan mereka yang mendukung keadilan jender menyadari pentingnya cara pembelajaran di kelas (Arivia, 2006: 421). Mereka menyerukan harus ada pembelajaran yang kritis, para guru tidak memakai bahasa yang bias jender. Oleh karena itu, para guru perlu memahami dasar-dasar HAM, sehingga dapat mengatur bahasanya yang sesuai dengan semangat HAM. Seringkali ada kecenderungan guru untuk menempatkan posisi siswa lelaki lebih tinggi dari siswa perempuan. Padahal, pendidikan seharusnya memberikan kesempatan kepada semua pihak untuk memperoleh posisi yang sejajar, dengan mengacu pada usaha, kerja keras dan bukan atas dasar hak istimewa (Puskur, 2009).

Guru sangat dibutuhkan dalam mentransformasi pengetahuan dan nilainilai kehidupan pada diri anak-anak, proses ini membentuk perkembangan pola pikir, tingkah laku dan mozaik kepribadian manusia sebagai mahluk sosial, termasuk di dalamnya pandangan mengenai peran manusia berdasarkan jenis seks atau peran jender Kusumaningrum (2007). Oleh karena itu, untuk menanamkan nilai-nilai keadilan dan kesetaraan jender pada generasi 
muda sehingga tercipta masyarakat yang berkeadilan jender dan saling menghormati dan menghargai antarsesama, guru bukan hanya menyampaikan materi pembelajaran secara harafiah saja, tetapi juga melakukan interpretasi terhadap materi yang disampaikan. Guru yang dapat membuat interpretasi yang baik hanyalah guru yang memiliki pengethuan dalam hal-hal yang formal dalam karya sastra (alur, penokohan, tema, dsb.) dan memiliki pemahaman komprehensif mengenai jender.

Strategi pembelajaran sastra berperspektif jender ini tidak jauh berbeda pada strategi pembelajaran sastra yang sudah ada selama ini misalnya dengan pendekatan transaksional. Hanya saja, penekannya pada upaya dan kompetensi guru dalam memberikan alternatif interpretasi dari karya sastra yang mengandung nilai-nilai pendidikan jender yang belum umum dipahami oleh siswa. Oleh karena itu, pemahaman inilah yang menjadikan sosiliasasi ini penting untuk dilaksanakan dalam rangka memberikan pemahaman sejak dini kepada mahasiswa calon guru sastra maupun kepada para guru yang kini telah memberikan pembelajaran sastra di kelas. Guru yang sensitif jender, tentu akan menginterpretasi materi pembelajaran dengan baik dan bijak. Berbeda dengan guru yang buta jender, tentu akan kesulitan dalam menginterpretasi materi pembelajaran sehingga pesan atau ideoogi jender yang terdapat dalam karya sastra sulit untuk dipahami oleh siswa dan siswa pun tidak akan memiliki perhatian terhadap keadilan dan kesetaraan jender. Dengan demikian, untuk mencapai pembelajaran sastra yang berperspektif jender, penting disiapkan guru yang sensitif jender.

\section{Tujuan dan Manfaat}

Tujuan kegiatan pengabdian ini terbagi menjadi tujuan jangka pendek dan tujuan jangka panjang. Tujuan jangka pendek, yaitu agar peserta sosialisasi mampu memahami dan menguasai pembelajaran sastra berperspektif jender dari sisi kurikulum, materi ajar dan cara pembelajaran di kelas. Tujuan jangka panjang, mengadakan tindak lanjut dari kegiatan pengabdian ini berupa kegiatan pelatihan pemanfaatan materi pembelajaran sastra berperspektif jender.

Melalui kegiatan sosialisasi ini, membentuk guru SMA/SMK yang sensitif jender dan menguasai pembelajaran sastra berperspektif jender. Melalui sosialisasi ini, guru SMA/SMK dapat mengembangkan kepekaan sosialnya akan realitas jender di lingkungan sosialnya yang dapat dikelola dalam menghasilkan karya sastra berperspektif jender yang dapat dipublikasikan sehingga karya pribadi tersebut dapat digunakan dalam pembelajaran sastra berperspektif jender di kelas-kelas yang diampunya.

\section{METODE PELAKSANAAN}

Permasalahan guru yang berkaitan dengan keterbatasannya terhadap pembelajaran sastra berperspektif jender menjadi kendala penanaman nilai-nilai keadilan dan kesetaraan jender pada generasi muda (siswa) dalam rangka menciptakan masyarakat yang berkeadilan jender dan saling menghormati dan menghargai antarsesama. Agar gagasan pembelajaran sastra dapat tercapai, maka ada sejumlah hal yang perlu diperhatikan, antara lain kurikulum, materi pembelajaran, strategi pembelajaran yang berprespektif jender, serta guru yang sensitif jender. Kegiatan pengabdian kepada masyarakat sebagai upaya pemecahan masalah tersebut menjadi salah satu alternatif menjembatani realita yang ada tersebut agar menjadi idealita, yaitu dengan mengadakan Sosialisasi Pembelajaran Sastra Berpers- 
pektif Jender bagi Guru SMA/SMK seSurakarta.

Realisasi pemecahan masalah yang dilakukan melalui sosialisasi ini, yaitu

1. Penyampaian materi yang dibutuhkan para guru terkait strategi, metode, teknik, dan materi pembelajaran sastra berperspektif jender.

2. Pemberian motivasi kepada para guru untuk memahami persoalan jender secara komprehensif.

3. Memberikan wawasan kepada guru untuk mampu mengelola pembelajaran sastra berperspektif jender yang menyenangkan di kelas.

4. Diskusi mengenai kendala-kendala dalam mengelola pembelajaran sastra berperspektif jender dan pemberian masukan sebagai upaya pemecahan kendala-kendala yang dialami para guru.

5. Tim pengabdian bersedia menjadi fasilitator kelanjutan diskusi antara pembicara dan guru dalam rangka membantu pelaksanaan pembelajran sastra berperspektif jender di sekolah.

Khalayak sasaran dalam kegiatan pengabdian ini, yaitu guru dari berbagai SMA/SMK se-Surakarta berjumlah 19 orang. Metode yang diterapkan untuk mencapai tujuan dalam PM ini adalah seminar, ceramah, tanya jawab dan diskusi tentang berbagai masalah dasar pembelajaran sastra berperspektif jender. Kegiatan ini dilengkapi dengan makalah dari para pemateri.

\section{HASIL DAN PEMBAHASAN}

Sosialisasi pembelajaran sastra berperspektif jender bagi guru SMA/SMK se-Surakarta diadakan selama satu hari. Sosialisasi ini dilaksanakan di Auditorium Mohamad Djazman pada hari Rabu tanggal 28 Mei 2010. Jumlah peserta yang mendaftar sebanyak 19 orang.
Sosialisasi dibuka oleh Wakil Dekan I FKIP UMS mewakil Dekan FKIP UMS. Sosialisasi dimulai pada pukul 09.00 WIB sampai dengan pukul 13.00 WIB. Adapun pemateri dalam sosialisasi ini, yaitu Prof. Dr. Suminto A. Sayuti (Guru besar Universitas Negeri Yogyakarta) dan Abidah El Khalieqy (Sastrawan). Pemateri I menyampaiakan materi dengan judul "Strategi BelajarMengajar Sastra Berperspektif Jender” dan pemateri II menyampaikan makalah dengan judul "Ramah Tamah Sastra, Perempuan dan Agama".

Sosialisasi ini dikemas dalam bentuk diskusi interaktif. Para pemateri memberikan pemaparan selama satu jam kemudian dibuka sesi tanya jawab yang dipandu oleh moderator. Setelah penjelasan yang disampaikan oleh pembicara, dibuka sesi tanya jawab dan diskusi yang dipandu oleh moderator.

Pembelajaran sastra berperspektif jender adalah proses belajar mengajar seni sastra yang kreatif dan ekspresif yang dijiwai oleh kesadaran adanya keadilan dan kesetaraan jender. Pembelajaran sastra berperspektif jender sebagai bagian dari proses pendidikan yang dijiwai oleh kesadaran adanya keadilan dan kesetaraan jender haruslah mempertimbangkan tiga komponen sebagai berikut: kurikulum, materi yang disampaikan atau diproduksi oleh institusi pendidikan, dan strategi pembelajaran di kelas yang keseluruhan itu menurut istilah Sayuti (2010: 1) merupakan suatu sistem lingkungan. Sistem lingkungan tersebut terdiri atas komponen-komponen yang saling mempengaruhi: (1) tujuan instruksional yang ingin dicapai; (2) materi yang diajarkan; (3) guru dan siswa yang harus memainkan peranan serta ada dalam hubungan sosial tertentu; (4) bentuk kegiatan yang dilakukan; dan (5) sarana dan prasarana belajarmengajar yang tersedia. 
Apapun tujuan yang akan dicapai guru dalam pembelajaran sastra yang pertama pertama dan utama yang harus selalu dipegang adalah bahwa penekanan pada siswa dan bukan pada guru. Untuk dapat melaksanakan tugas secara profesional, dalam arti memilih dan melaksanakan strategi belajar mengajar yang efektif, seorang guru membutuhkan wawasan yang cukup memadai tentang kermungkinankemungkinan strategi belajar-mengajar yang sesuai dengan tujuan-tujuan belajar, baik dalam arti efek instruksional maupun efek pengiring, yang ingin dicapai. Di samping itu, diperlukan penguasaan teknis di dalam mendesain sistem iingkungan belajarmengajar berikut implementasinya secara efektif. Hal yang demikian juga berlaku bagi strategi belajar mengajar dalam pendidikan sastra berperspektif jender.

Joyce dan Well (1980 dalam Sayuti, 2010: 2) mengemukakan adanya empat kelompok model-model mengajar. Pertama, model pengolahan informasi. Model ini bertitik tolak pada prinsip-prinsip pengolahan informasi: bagaimana manusia menangani rangsangan dan lingkungan, mengolah data, mendeteksi masalah, menyusun konsep, memecahkan masalah, dan menggunakan simbol-simbol.

Kedua, model personal. Modelmodel yang termasuk kelompok ini meletakkan nilai tertinggi pada perkembangan pribadi di dalam memandang dan "membangun” realitas, yang melihat manusia terutama sebagai makhluk pencipta dan pemberi makna. Oleh karena itu, proses pengorganisasian internal yang dilakukan individu serta pengaruhnya terhadap cara dan proses “pergaulan” individu tersebut dengan lingkungannya maupun dengan dirinya sendiri, meniadi sesuatu yang diutamakan dalam model ini. Karenanya pula, efek penting sistem lingkungan belajar juga mengedepan. Dalám model mi, pemben- tukan kapsitas personal untuk mencapai pemahaman dan penemuan diri sendiri sehingga terbentuk self-concept, cenderung diutamakan. Di samping itu, pembentukan kreativitas dan kernampuan rnemecahkan masalah secara kreatif, juga ditekankan.

Ketiga, model interaksi sosial. Model ini berdasarkan pada dua asumsi pokok, yaitu (a) masalah-masalah sosial diidentifikasi dan dipecahkan atas dasar dan melalui kesepakatan-kesepakatan yang diperoleh di dalam dan menggunakan proses-proses sosial; dan (b) proses sosial yang demokratis perlu dikembangkan untuk melakukan perbaikan masyarakat dalam arti seluas-luasnya secara built in dan terus-menerus.

Keempat, model behavioral. Model mi mementingkan penciptaan sistem lingkungan belajar yang memungkinkan manipulasi penguatan tingkah laku secara efektif sehingga terbentuk pola tingkah laku yang dikehendaki.

Penerapan model pengajaran sastra yang berperspektif jender juga harus mempertimbangkan hal-hal berikut ini.

1. Pentimbangan dan perspektif literer juga tidak boleh ditinggalkan. Perlu diperhatikan prinsip peranan pembaca dalam proses yang melaluinya mereka menafsirkan sastra, memungkinkan emosi dan intelektualnya berfungsi kontributif untuk membangkitkan pengalaman literer.

2. Membangkitkan harapan. mengubah, memeriksa, dan memperluas kesan serta memecahkan teka-teki dalam teks sastra. Aktivitas yang bertahap itu dapat dikembangkan melalui pembelajaran sastra.

3. Para siswa dapat dibantu untuk mengajukan pertanyaan secara aktif dan, jika diperlukan, menyanggah teks: mereka dibawa masuk ke dalam situasi “perseteruan” dengan teks yang sedang dibacanya. Hal ini dapat dilakukan melalului (1) mem- 
formulasikan teka-teki mereka sendiri dan bukannya menjawab pertanyaan guru; (2) melakukan spekulasi dan merumuskan hipotesis; dan (3) mencocokkan ideologi-ideologi tekstual dengan ideologi yang dimiliki para siswa.

4. Learner-learning tetap menjadi prioritas utama. Guru tetap menduduki posisinya yang utama tetapi, posisi utama itu tidak dalam artinya yang selalu berorientasi pada tindakan teacher-teaching melainkan kapasitas dan kemampuan guru dalam mengarahkan dan memberikan dorongan kepada para siswa (learner-learning).

5. Strategi tansaksional tepat digunakan dalam pembelajaran sastra. Transaksi itu pada hakikatnya merupakan konversasi atau dialog terus-menerus antara teks dan pembaca: "sebuah negosiasi antara apa yang diketahui pembaca dan apa yang disajikan teks. Strategi pembelajaran sastra berperspektif jender ini tidak jauh berbeda pada strategi pembelajaran sastra yang sudah ada selama ini misalnya dengan pendekatan transaksional. Hanya saja, penekannya pada upaya dan kompetensi guru dalam memberikan alternatif interpretasi dari karya sastra yang mengandung nilai-nilai pendidikan jender yang belum umum dipahami oleh siswa. Oleh karena itu, pemahaman inilah yang menjadikan sosiliasasi ini penting untuk dilaksanakan dalam rangka memberikan pemahaman sejak dini kepada mahasiswa calon guru sastra maupun kepada para guru yang kini telah memberikan pembelajaran sastra di kelas.

6. Perhatikan struktur bahasa sebagai medium sastra. Bahasa adalah rumah persembunyian terbaik bagi ideologi. Oleh sebab itu, sastra yang bermedium mampu membentuk kesadaran dan perspesi kita, baik secara diam-diam maupun terang-terangan, termasuk di dalamnya adalah kemungkinan potensinya dalam membangun perspektif jender. Ideologi phallocentrism secara mendalam distrukturkan dalam dan menstrukturkan tentang masyarakat patrialkhal. Dalarn banyak hal, kebenaran adalah sebuah fungsi yang mengendalikan wacana, sementara laki-laki memiliki kekuatan dalam masyarakat karena mampu mengendalikan bahasa. Feminisme bermaksud untuk rnendkonstruksi tidak hanya oposisi laki-laki perempuan, tetapi juga seluruh bentuk kekuatan sosial, status, ketidaksamaan, dan dominasi. Karena itu, pengajaran sastra, yang kurikulumnya umumnya didominasi oleh teks-teks mengenai pengalarnan perempuan yang dihasilkan laki-laki dan memaparkan perempuan dan sudut pandang laki-laki, sudah saatnya diperhitungkan kembali. Ketika karya penulis perempuan dijadikan materi pengajaran, kajian tersebut hendaknya proporsional. Artinya, jangan hanya terbatas pada perhatian posisi mereka sebagai penulis perempuan, tetapi hendaknya sampai dalam konstelasinya dalam tradisi laki-laki. Pada prinsipnya, para siswa hendaknya dapat dibantu untuk memilih bagaimana membaca teks tertentu dan menjadi sadar terhadap "wacana-wacana” yang telah dimilikinya, yang hakikatnya tidak pernah singular. Sebenamya, yang dibutuhkan dalam ruang-ruang pembelajaran bukan hanya dicantumkannya teks-teks yang ditulis oleh para wanita, melainkan dilaksanakannya pembelajaran, misalnya menulis (kreatif), bagi dan oleh para siswa perempuan mengenai realitas pengalaman mereka dan kemungkinan pentransformasiannya. 
Karya sastra yang bersifat fiksi memiliki kekuatan untuk mengisahkan, dan menyatukan kembali gambaran manusia yang diturunkan dari perspektif perempuan dan laki-laki. Seabagaimana yang disampaikan Khalieqy (2010: 4) bahwa dunia fiksi telah dinyata memiliki kekuatan tersendiri untuk mengisahkan, memungut dan menyatukan kembali sobekan potret manusia yang diturunkan dari wajah Adam dan Hawa. Kesatupaduan karakter, serta jalinan kepribadian antara laki-laki dan perempuan itu menjadi tema-tema yang menarik untuk digali dan dikembangkan. Sastra adalah pergulatan antara imajinasi dan realitas kehidupan, dan kehidupan bukan milik lelaki saja atau perempuan saja. Sehingga sastra perlu juga menelusuri ide, kisah dan inti cerita yang berfungsi sebagai media untuk membangkitkan kesadaran atas berbagai persoalan yang dihadapi oleh perempuan dari zaman ke zaman.

Dengan adanya proses-proses penciptaan sastra yang peka dan sejalan dengan laju perubahan budaya maka proses pembelajaran sastra pun demikian. Kepekaan itu diperlukan karena penindasan terhadap perempuan juga kian berkembang dalam bentuk baru yang lebih sistemik maka pembelajaran sastra berperspektif jender pun haruslah dikelola lebih sistematik.

\section{Antusias, Responsi, dan Keaktifan Peserta Pelatihan}

Selama kegiatan ini peserta antusias dan bersemangat. Dalam penyajian materi, biasanya peserta cenderung akan pasif dan 'menerima' saja. Namun dalam sosialisasi ini, peserta aktif dan responsif. Mereka antusias mengikuti jalannya kegiatan dari awal sampai akhir berbagai penyajian dengan baik dan semangat. Indikator tersebut dibuktikan dengan hal-hal berikut ini.
1. Banyaknya pertanyaan kritis yang disampaikan peserta kepada pemateri dari awal hingga akhir dalam sesi tanya jawab.

2. Dalam umpan balik yang diisi oleh para peserta seusai acara yang menyatakan materi dan penyampainnya umumnya baik, pelaksanaan teknis dan pemberian motivasi dari pembicara pun mendapat penilaian baik dari peserta.

\section{SIMPULAN DAN SARAN}

\section{Simpulan}

Berdasarkan hasil dan pembahasan pelaksanaan kegiatan pengabdian masyarakat ini dapat disimpulkan beberapa hal berikut ini.

a. Melalui kegiatan sosialisasi ini para guru mendapatkan materi yang dibutuhkan terkait strategi, metode, teknik, dan materi pembelajaran sastra berperspektif jender.

b. Para guru termotivasi untuk memahami persoalan jender secara komprehensif.

c. Wawasan para guru untuk mengelola pembelajaran sastra berperspektif jender yang menyenangkan di kelas bertambah. Hal ini disebabkan adanya diskusi mengenai solusi dari kendala-kendala yang dihadapi guru dalam mengelola pembelajaran sastra berperspektif jender.

\section{Saran}

Saran ini terkait dengan masalah publikasi kegiatan. Hendaknya pihak sekolah terutama kepala sekolah dan Tata Usaha ikut partisipasi aktif dengan memperlancar distribusi surat ke para guru sehingga kegiatan ini dapat diikuti oleh lebih banyak sekolah dan dapat disebarluaskan kebermanfaatannya. 


\section{DAFTAR PUSTAKA}

Arivia, Gadis. 2006. Feminisme Sebuah Kata Hati. Jakarta: Penerbit Buku Kompas.

Asmoro, Donny. 2006. “Ketidakadilan Gender dalam Novel Perempuan Jogja Karya Achmad Munif”. Skripsi. Jurusan Sastra Indonesia. Universitas Negeri Malang.

Endraswara, Suwardi. 2005. Metode dan Teori Pengajaran Sastra. Yogyakarta: Buana Pustaka. Inpres No. 9 Tahun 2000, berupa keputusan untuk melakukan Gender Mainstreaming.

Irawan, Ade HM., Meti Istimurti, dkk. "Peran Karya Sastra dalam Memperkenalkan Wacana Gender pada Siswa di Sekolah Dasar”. Makalah. Konferensi Internasional Kesusastraan XIX / Hiski halaman 1 dari 16, Batu, 1214 Agustus 2008.

Khalieqy, Abidah El. 2010. "Ramah Tamah Sastra, Perempuan, dan Agama”. Surakarta: Makalah disampaikan dalam Seminar Sastra Berperspektif Jender pada 28 April 2010 di Auditorium Mohamad Djazman UMS.

Kusumaningrum, Desi Eri; Muslihati. 2007. "Wacana Kesetaraan Gender dalam Pembelajaran di Kelas Tinggi Minu Kraksaan Probolinggo”. Skripsi. Universitas Negeri Malang.

Macdonald, Mandy, dkk. 1997. Gender dan Perubahan Organisasi. Terjemahan oleh Mansyur Fakih. 1999. Jakarta: Pustaka Pelajar.

Purwahida, Rahmah. 2008. "Pembelajaran Sastra di kelas X Rintisan Sekolah Bertaraf Internasional SMA Negeri 8 Yogyakarta”. Skripsi. Fakultas Bahasa dan Seni, Universitas Negeri Yogyakarta.

Puskur. 2009. "Kurikulum”. www.puskur.net. diakses 1 April 2010.

Riza Ayu Pradani. 2007. "Novel Perempuan Badai Karya Mustofa W. Hasyim: Tinjauan Kritik Sastra Feminis”. Skripsi. Fakultas Sastra dan Seni Rupa Universitas Sebelas Maret Surakarta.

Sayuti, Suminto A. 1994. Pengantar Pengajaran Puisi dalam Pengajaran Sastra. Jabrohim ED. Yogyakarta: Pustaka Pelajar.

Sayuti, Suminto A. 2010. “Strategi Belajar-Mengajar Sastra Berperspektif Gender”. Surakarta: Makalah disampaikan dalam Seminar Sastra Berperspektif Jender pada 28 April 2010 di Auditorium Mohamad Djazman UMS.

Susilaningsih, dkk. 2004. Gender dalam Pembangunan. Yogyakarta: PSW IAIN Sunan Kalijaga Press.

Sumiadi, M. 2009. "Ideologi Gender dalam Wacana Novel Indonesia Dasawarsa 1990 -an dan 2000-an”. Laporan Penelitian. LPPM Universitas Pendidikan Indonesia.

Wiyatmi. “Menggagas Pembelajaran Sastra Berprespektif Gender” Konferensi Internasional Kesusastraan XIX / Hiski halaman 1 dari 15, Batu, 1214 Agustus 2008. 